\title{
Fusarium oxysporum causing Black Gram Wilt a New Threat in the Western Undulated Zones of Odisha
}

\author{
K. Biswal ${ }^{1}$, K. C. Sahu ${ }^{2}$, N. Ranasingh ${ }^{3^{*}}$ and R. L. Moharana ${ }^{4}$ \\ (PPT), College of Agriculture, BBSR, India \\ (PPT), College of Agriculture, OUAT, India \\ (PPT), College of Agriculture, Bhawanipatna, India \\ (SST), College of Agriculture, Bhawanipatna, India \\ *Corresponding author
}

A B S T R A C T

\section{Ke ywords \\ Black gram, \\ Fusarium \\ oxysporum, Protein \\ and seed yield \\ Article Info \\ Accepted: \\ 21 May 2020 \\ Available Online: \\ 10 June 2020}

Black gram (Vigna mungo L.) belongs to the family Fabaceae is an excellent sources of protein (25\%), B-complex vitamins, rich source of micronutrients like iron $(7.5 \mathrm{mg})$ and copper-109\% is being now affected by Fusarium oxysporum in the Kharif season in western undulated zones of Odisha thereby reducing protein content by $4-5 \%$ and yield by $15-$ $20 \%$ a new report.

\section{Introduction}

Black gram is much affected by various diseases such as Anthracnose (Colletotrichum lindemuthianum), Bacterial leaf blight (Xanthomonas phaseoli), Cercospora leaf spot (Cercospora canescens), Powdery mildew (Erysiphe polygoni), Root rot and leaf blight (Rhizoctonia solani), Rust (Uromyces phaseoli), Macrophomina blight (Macrophomina phaseolina), Yellow mosaic disease (Mungbean yellow mosaic virus),
Leaf crinkle disease (Leaf crinkle virus) in Odisha and also in India. Diseases are one of the principal cause about the decline in the productivity of black gram from $\left(575 \mathrm{~kg}^{-\mathrm{ha}}\right)$ to $418 \mathrm{~kg}^{\text {-ha }}$ in Odisha as compared to national average.

Presently, a new fungal wilt caused by Fusarium oxysporum noticed in pulses growing districts of Western undulated zones of Odisha which drastically reduces protein content by $4-5 \%$ and yield by $15-20 \%$. 
Total world area under pulses is 85.40 Mha with production of 87.40 MT and productivity: $1023 \mathrm{~kg} / \mathrm{ha}$ (Source: Ministry of Agriculture \& Farmers welfare 2017-18). In India pulses production 25.23 MT with an area of 29 Mha and productivity of $841 \mathrm{~kg} / \mathrm{ha}$. In India Black gram Production 3.56MT with an area of 5.44 Mha and a productivity of 655 $\mathrm{kg}$ /ha (Source: Ministry of Agriculture \& Farmers welfare 2017-18).

The black gram crop is affected by various biotic and abiotic factors in Odisha as well as in India. Among which biotic factors includes different diseases such as Anthracnose, Bacterial leaf blight Cercospora leaf spot, Powdery mildew Root rot and leaf blight ,Rust , Macrophomina blight, Yellow mosaic disease, Leaf crinkle disease in Odisha. Besides these above diseases now one type of new wilting disease just like dry root rot of black gram was noticed in different pulses growing districts of Odisha mostly observed in the western undulating zones particularly in Nuapada and Bhawanipatna regions of Odisha causing $15-20 \%$ yield loss in Kharif as well as in Rabi and noticed at flowering to post flowering stage.

\section{Materials and Methods}

Several field visits were made during Kharif 2016 and Rabi 2017 in the pulse growing regions of Nuapada and Bhawanipatna. The disease samples were collected from the farmer's field and cleaned in the laboratory and the disease symptoms were examined in the laboratory.

\section{Symptoms}

The wilting symptoms were observed at 30 40 days after sowing. The leaves of the affected plant turn yellowing prematurely, foliage droops and within 4-5 days the plants wilt. Within 6-7 weeks plants of all ages may be affected. The disease appears sporadically on a few plants, later spreads in concentric circles to nearby plants. In severe cases large patches of wilted plants observed in the field. The symptom spread upwards along the stem to several inches above ground level down wards along the tap and lateral roots causing dry rot.

\section{Causal organism}

\section{Fusarium oxysporum}

The fungus is mainly confined to vascular tissues and is present both inter and intra cellular. If a diseased stem or root, particularly from the near soil surface is examined in transverse section under a microscope, the large number of fungal hyphae can be seen mostly in the vascular bundles. The host cells were also found discolored brown.

\section{Results and Discussion}

\section{Symptoms}

Joshi (2018) suggested Fusarium oxysporum is the causative agent of Fusarium wilt which has proved to be the most destructive disease affecting a wide range of plants comprising of weeds and commercially domesticated plants and crops.

The disease results in varied symptoms ranging yellowing of leaves, browning of vascular tissues, retarded growth and even plant death. Due to its soilborne nature and perennial nature of its hosts Fusarium management has been a challenge. Suji Park (2014) were also reported similar types of symptoms in Fusarium wilt noticed in Carnation plant caused by Fusarium oxysporum f. sp. dianthi (Fod ) which has been a major limitation for carnation production worldwide as well as in Korea (Fig. 1 and 2; Table 1). 
Table.1 The conidial measurement of Fusarium oxysporum by Research Microscope "LABOVISION KX 2000" under 20X

\begin{tabular}{|c|c|c|c|c|c|c|c|c|c|c|c|c|}
\hline $\begin{array}{l}\text { SL. } \\
\text { No. }\end{array}$ & Length & Width & Area & $\begin{array}{l}\text { Asp. } \\
\text { Ratio }\end{array}$ & $\begin{array}{c}\text { Round } \\
\text { ness }\end{array}$ & Shape & $\begin{array}{c}\text { Box } \\
\text { Area }\end{array}$ & Centroid X & Centroid Y & Elongation & Orientation & $\begin{array}{c}\text { Circle } \\
\text { Diameter }\end{array}$ \\
\hline 1 & 3.78 & 1.18 & 9.46 & 3.18 & 23.729 & 0.04 & 9.465 & 51 & 165 & 10.61 & 78 & 6.945 \\
\hline 2 & 9.20 & 2.10 & 17.239 & 4.37 & 32.692 & 0.031 & 17.239 & 144 & 161 & 7.986 & 56 & 9.372 \\
\hline 3 & 28.26 & 5.09 & 108.16 & 5.54 & 17.897 & 0.05 & 108.167 & 115 & 210 & 9.492 & 143 & 23.477 \\
\hline 4 & 18.53 & 3.78 & 54.75 & 4.89 & 20.558 & 0.04 & 54.759 & 774 & 245 & 8.112 & 203 & 16.704 \\
\hline 5 & 23.43 & 3.23 & 55.77 & 7.24 & 11.089 & 0.09 & 55.773 & 653 & 667 & 13.76 & 46 & 16.858 \\
\hline
\end{tabular}

\begin{tabular}{|c|c|c|c|c|c|c|c|c|c|}
\hline $\begin{array}{l}\text { Sl. } \\
\text { No. }\end{array}$ & $\begin{array}{l}\text { Sphare } \\
\text { Volume }\end{array}$ & Major Axis & $\begin{array}{l}\text { Minor } \\
\text { Axis }\end{array}$ & $\begin{array}{l}\text { Thread } \\
\text { Length }\end{array}$ & $\begin{array}{l}\text { Thread } \\
\text { Width }\end{array}$ & $\begin{array}{l}\text { Fibre } \\
\text { Length }\end{array}$ & $\begin{array}{l}\text { Fibre } \\
\text { Width }\end{array}$ & Min. Radius & $\begin{array}{l}\text { Max. } \\
\text { Radius }\end{array}$ \\
\hline 1 & 518.528 & 3.784 & 0.143 & 8.965 & 1.056 & 10.021 & 0.944 & 0.581 & 3.536 \\
\hline 2 & 1274.649 & 9.205 & 1.163 & 10.011 & 1.722 & 11.733 & 1.469 & 0 & 4.193 \\
\hline 3 & 20033.664 & 28.263 & 2.878 & 28.207 & 3.835 & 32.042 & 3.376 & 1.163 & 14.074 \\
\hline 4 & 7216.19 & 18.531 & 2.056 & 18.041 & 3.035 & 21.076 & 2.598 & 1.163 & 9.393 \\
\hline 5 & 7417.565 & 23.434 & 1.933 & 25.517 & 2.186 & 27.702 & 2.013 & 0.822 & 12.804 \\
\hline
\end{tabular}




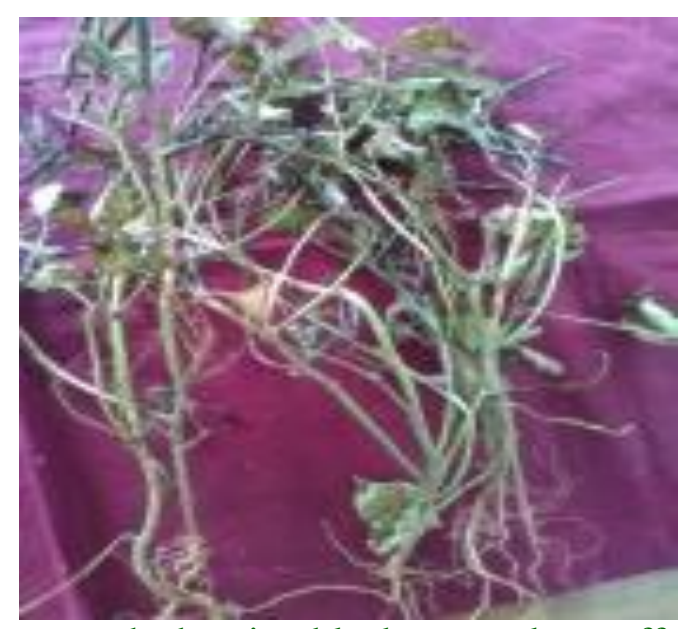

Fig.1 Field photograph showing black gram plants affected by wilting caused by Fusarium oxysporum

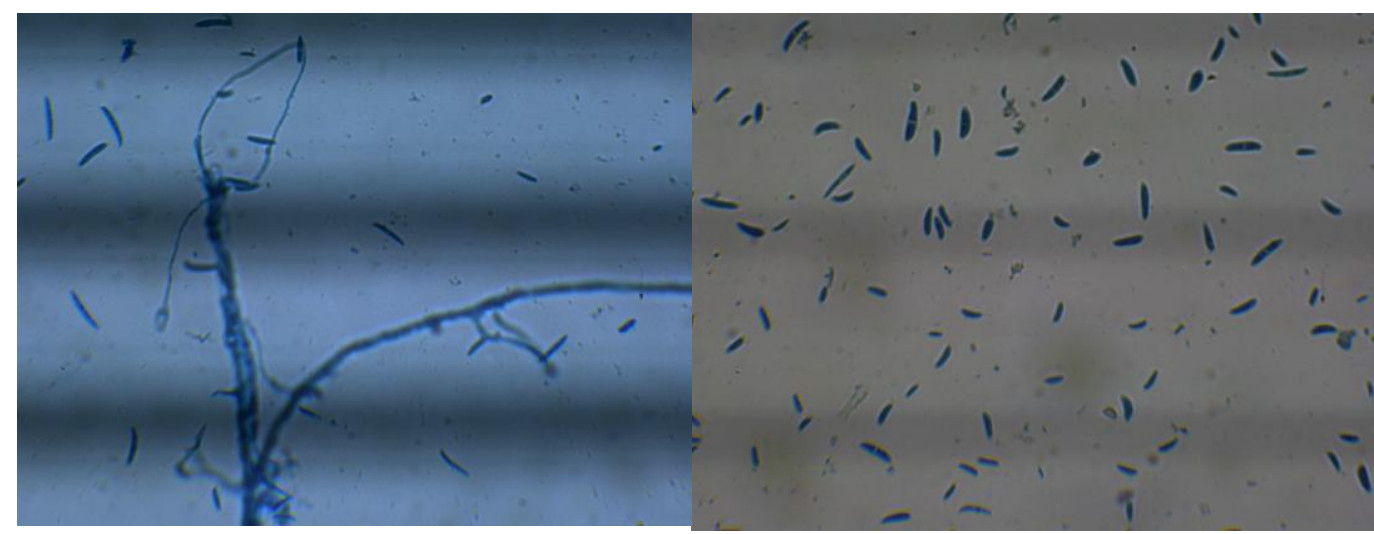

Fig.2 Conidia of Fusarium oxysporum under labovision KX 2000 under 20X

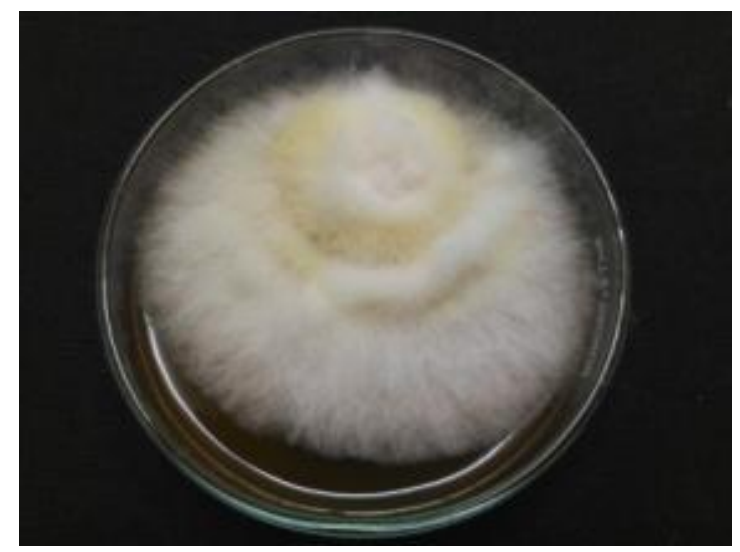

Plate.1 Mycelial characteristics of Fusarium oxysporum after 8 days of incubation

\section{Hyphae and conidial ontogeny}

The fungus was identified basing on cultural and morphologically characteristics cited by Booth, C.1977 


\section{Cultural characteristics of Fusarium oxysporum isolate}

The fungus was isolated using PDA medium taking one affected tissue of cut piece measuring $0.5-1.0 \mathrm{~cm}$. The mycelial growth of the fungus was profusely produced in Potato Dextrose Agar medium and sporulation was also maximum within 8days of incubation at $25^{\circ} \mathrm{C} \pm 2$ in the BOD incubator. Potato dextrose agar was the best medium for both the mycelial growth and sporulation. The fungus was identified based on growth of aerial mycelia, mycelia texture, radial mycelia growth (colony diameter, sporulation) on PDA medium after 8 days of incubation at $25^{\circ} \mathrm{C} \pm 2$.

\section{Hyphae}

The mycelium of Fusarium oxysporum was septate, hyaline, slender and highly branched (Plate 1). White colour to slightly brownish white luxuriant aerial mycelia was observed during the growth of the fungus. Conidiophores appear from the hyphae and were either single or branched. Monophialides were produced at the tip of the conidiophores. Chlamydospores were also produced on hyphae of 2-3 week old cultures of the isolates and were terminally or intercalary, single or in chains, globose or oval in shape.

\section{Conidia}

The Fungus produces macro as well as micro conidia. Micro conidia were borne on micro conidiophores. Micro conidia were thin- walled, hyaline, 0-1 septate (mostly 0 septate), slightly straight to curved, fusoid, scattered. Macro conidia were produced on macro conidiophores. Macroconidia were thin walled, hyaline, falcate in nature. Tip portions highly curved. The macro conidia were 4-5 septate with very rarely 6-7 septate. The measurement of five different conidia was made with the help of LABOVISION KX 2000 Research Microscope under 20x in the department of Plant Pathology, College of Agriculture Bhawanipatna. Conidial measurements in microns were presented in Table 1. The length varies from 3.7-28.2 $\mu$ and width varies from 1.1-5.9 $\mu$. All other characteristics like circle diameter thread length and width were also presented for references.

\section{References}

Booth, C. 1977. Fusarium Laboratory guide to the Identification of the major species. CMI, Ferry Lane, Kew, Surrey. Pp. 37.

Joshi, Renu. 2018. A review of Fusarium oxysporum on its plant interaction and industrial use. Journal of Medicinal Plants Studies; 6(3): 112-115

Park, Suji, Lee, Ji Won, Yoo, Bong Sik, Sook Han, Kyung- and Kim, Jin-Won.2014. Pathogenicity Test of Fusarium oxysporum $f$. sp. dianthi on Korean Carnation (Dianthus caryophyllus) Cultivars. Department of Environmental Horticulture, The University of Seoul, Seoul 130-743, Korea.

\section{How to cite this article:}

Biswal, K., K. C. Sahu, N. Ranasingh and Moharana, R. L. 2020. Fusarium oxysporum causing Black Gram Wilt a New Threat in the Western Undulated Zones of Odisha. Int.J.Curr.Microbiol.App.Sci. 9(06): 3027-3031. doi: https://doi.org/10.20546/ijcmas.2020.906.364 